\title{
Casting light on intracellular tracking of a new functional graphene-based microRNA delivery system by FLIM and Raman imaging
}

Anna Piperno ${ }^{*} \dagger$, Antonino Mazzaglia ${ }^{\ddagger}$, Angela Scala ${ }^{\dagger}$, Rosamaria Pennisi ${ }^{\dagger,}$, Roberto Zagami ${ }^{\ddagger}$, Giulia Neri ${ }^{\dagger}$, Serena M Torcasio ${ }^{\dagger}$, Consolato Rosmini ${ }^{\dagger}$, Placido G Mineo ${ }^{\|}$, Monica Potara ${ }^{\perp}$, Monica Focsan ${ }^{\perp}$, Simion Astilean ${ }^{\perp}, \#$, Grace Guoying Zhou ${ }^{\S}$ and Maria Teresa Sciortino ${ }^{* \dagger}$

${ }^{(\dagger)}$ Department of Chemical, Biological, Pharmaceutical and Environmental Sciences, University of Messina, V.le F. Stagno d'Alcontres 31, 98166 Messina, Italy.

(‡) CNR-ISMN clo Dep. of Chemical, Biological, Pharmaceutical and Environmental Sciences; University of Messina, V.le F. Stagno d'Alcontres 31, 98166 Messina, Italy

(§) Shenzhen International Institute for Biomedical Research, Shenzhen, Guangdong, China

(I) Department of Chemical Sciences, University of Catania, V.le A. Doria 6, 95125, Catania, Italy.

( $\perp$ Nanobiophotonics and Laser Microspectroscopy Center, Interdisciplinary Research Institute in Bio-Nano-Sciences, Babes-Bolyai University, T. Laurian Str. 42, 400271 Cluj-Napoca, Romania.

(\#) Department of Biomolecular Physics, Faculty of Physics, Babes-Bolyai University, M Kogalniceanu Str. 1, 400084 Cluj-Napoca, Romania.

*Corresponding author: apiperno@unime.it, mtsciortino@unime.it

Cell Culture

Probe Loading and Entrapment Efficiency

$\mathrm{S}-2$

Dynamic light scattering (DLS) and $\zeta$-Potential measurements of GCD@Ada-Rhod S-3

Biological Evaluation S-4 References 


\section{CELL CULTURE}

Murine colon carcinoma cells (C26, Cell Line Service, Germany) were grown in RPMI culture medium (Lonza), supplemented with $2 \mathrm{mM}$ L-glutamine, penicillin/streptomycin $100 \mathrm{U} / \mathrm{mL}, 10 \%$ fetal calf serum and incubated in a humidified incubator $\left(37^{\circ} \mathrm{C}, 5 \% \mathrm{CO}_{2}\right)$.

Kidney epithelial cells from African green monkey, (Vero, American Type Culture Collection, ATCC) were propagated in EMEM (Lonza, Belgium), supplemented with $6 \%$ fetal bovine serum (FBS, Euroclone), $100 \mathrm{U} / \mathrm{ml}$ penicillin and $100 \mu \mathrm{g} / \mathrm{ml}$ streptomycin mixture (Lonza, Belgium). Human epithelial type 2 cells from laryngeal carcinoma, (HEp-2, American Type Culture Collection, ATCC), were grown in RPMI 1640 medium (Lonza,Belgium) supplemented with 10\% FBS, $100 \mathrm{U} / \mathrm{ml}$ penicillin and $100 \mu \mathrm{g} / \mathrm{ml}$ streptomycin mixture. Wild type acute monocytic leukemia (THP-1) cells, kindly provided by Prof. Bernad Roizman (Kovler Laborators, University of Chicago, USA), were maintained in RPMI-1640medium (Lonza, Belgium) supplemented with $10 \%$ FBS (Euroclone), $100 \mathrm{U} / \mathrm{mL}$ penicillin and $100 \mathrm{U} / \mathrm{mL}$ streptomycin, $1 \mathrm{mM}$ Sodium Piruvate, $10 \mathrm{mM}$ Hepes Buffer. Human monocyte from histiocytic lymphoma (U937, American Type Culture Collection, ATCC) cells were propagated in RPMI 1640 medium (Lonza, Belgium) supplemented with $2 \mathrm{mM} \mathrm{L}$-glutamine, $100 \mathrm{U} / \mathrm{ml}$ penicillin, $100 \mu \mathrm{g} / \mathrm{ml}$ streptomycin, and 10\% FBS (Euroclone). All cell lines were maintained at $37^{\circ} \mathrm{C}$ in a $5 \% \mathrm{CO}_{2}$ incubator.

\section{PROBE LOADING AND ENTRAPMENT EFFICIENCY}

The loading of Ada-Rhod amount GCD@Ada-Rhod complex was calculated by emission spectroscopy analyses after disassembling of complex in DCM. The emission spectrum of the GCD@Ada-Rhod organic dispersion(0.75 mg of GCD@Ada-Rhod in $1 \mathrm{~mL}$ of $\mathrm{CH}_{2} \mathrm{Cl}_{2}$ ) showed the typical band of fluorophore which increases its emission intensity as a function of time (Figure S1). After $24 \mathrm{~h}$ the intensity of fluorescence emission maximum was unchanged. The emission calibration curve of Ada-Rhod in DCM was performed in concentration range of 2.5-200 $\mu \mathrm{M}$ (Figure S2). The analyses indicated a probe loading and an encapsulation efficiency percentages of $2.7 \%$ and $71 \%$, respectively.

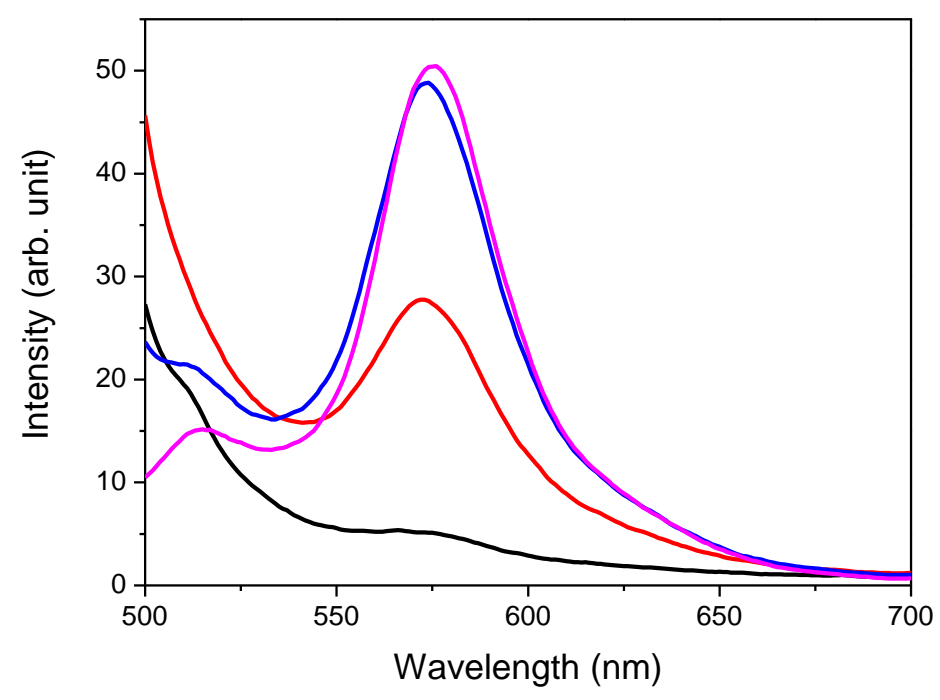


Figure S1. Fluorescence emission spectra of GCD@Ada-Rhod in DCM vs time ( $\mathrm{t}=0$ black line, $\mathrm{t}=1 \mathrm{~h}$ red line, $\mathrm{t}=5 \mathrm{~h}$ blue line, $\mathrm{t}=24 \mathrm{~h}$ magenta line). [GCD@Ada-Rhod] $=0.75 \mathrm{mg} / \mathrm{mL}$, [Ada-Rhod] $=71.5 \mu \mathrm{M}, \lambda_{\mathrm{exc}}=480 \mathrm{~nm}$.

The actual probe loading and entrapment efficiency (EE \% ) were calculated, respectively, using the equations here reported:

Probe loading $(\%)=($ amount of Ada-Rhod in GCD@Ada-Rhod /weighted amount of GCD@AdaRhod) X 100

$\mathrm{EE}(\%)=$ (amount of Ada-Rhod in GCD@Ada-Rhod /amount of Ada-Rhod initially added to formulation) X100

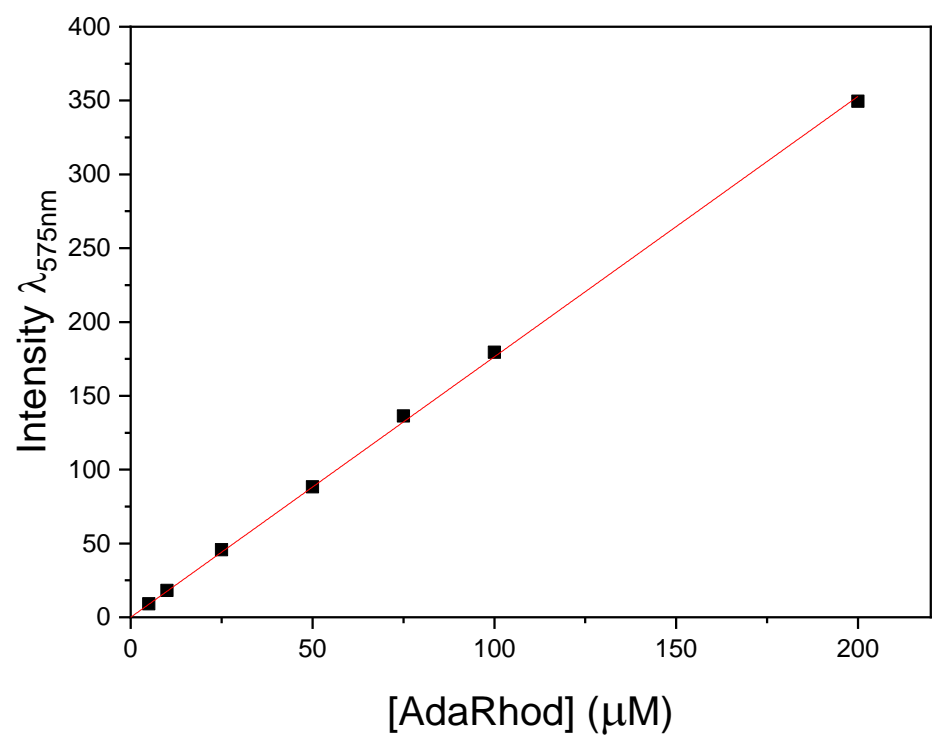

Figure S2. Calibration curve by fluorescence emission of Ada-Rhod in DCM $\left(\lambda_{\text {exc }}=480 \mathrm{~nm}, \mathrm{R}^{2}=\right.$ 0.99976).

\section{Dynamic light scattering (DLS) and $\zeta$-Potential measurements of GCD@Ada-Rhod}

To investigate the colloidal behaviour of the GCD@Ada-Rhod complex in aqueous dispersion $\zeta$ Potential and dynamic light scattering (DLS) measurements (Table 1) in infinite dilution conditions were performed. ${ }^{1}$

Table S1. Mean hydrodynamic diameter $\left(\mathrm{D}_{\mathrm{H}}\right)$, polidispersity index $(\mathrm{PDI})$ and $\zeta$-Potential

\begin{tabular}{|l|l|l|l|}
\hline System & $\mathrm{D}_{\mathrm{H}}(\mathrm{nm} \pm \mathrm{SD})(\%)$ & PDI & $\zeta(\mathrm{mV} \pm \mathrm{SD})$ \\
\hline
\end{tabular}




\begin{tabular}{|c|c|c|c|}
\hline $\begin{array}{c}\text { GCD@ Ada- } \\
\text { Rhod }\end{array}$ & $423 \pm 52(100)$ & 0.25 & $-37 \pm 7$ \\
\hline GCD & $>1 \mu \mathrm{m}$ & $\geq 0.4$ & $-9.5 \pm 0.3$ \\
\hline
\end{tabular}

\section{BIOLOGICAL EVALUATION}

\section{Evaluation of cellular uptake}

HEp-2, THP-1, U937 and Vero cell lines were untreated or treated with $100 \mu \mathrm{g} / \mathrm{mL}, 50 \mu \mathrm{g} / \mathrm{mL}$ and $25 \mu \mathrm{g} / \mathrm{mL}$ of GCD@ADA-Rhod for 24 hours, to investigate the intracellular uptake. After the indicated incubation time, the intracellular fluorescence of GCD@ADA-Rhod was evaluated thought fluorescence microscope observation. Cells were layered on poly-lysinated slides and analysed with standard DAPI/FITC/TRITC filter sets in a Biomed Fluorescence microscope (Letiz, Wetzlar, Germany). The nuclei were stained with Hoechst 33342 fluorescent DNA-binding dye.

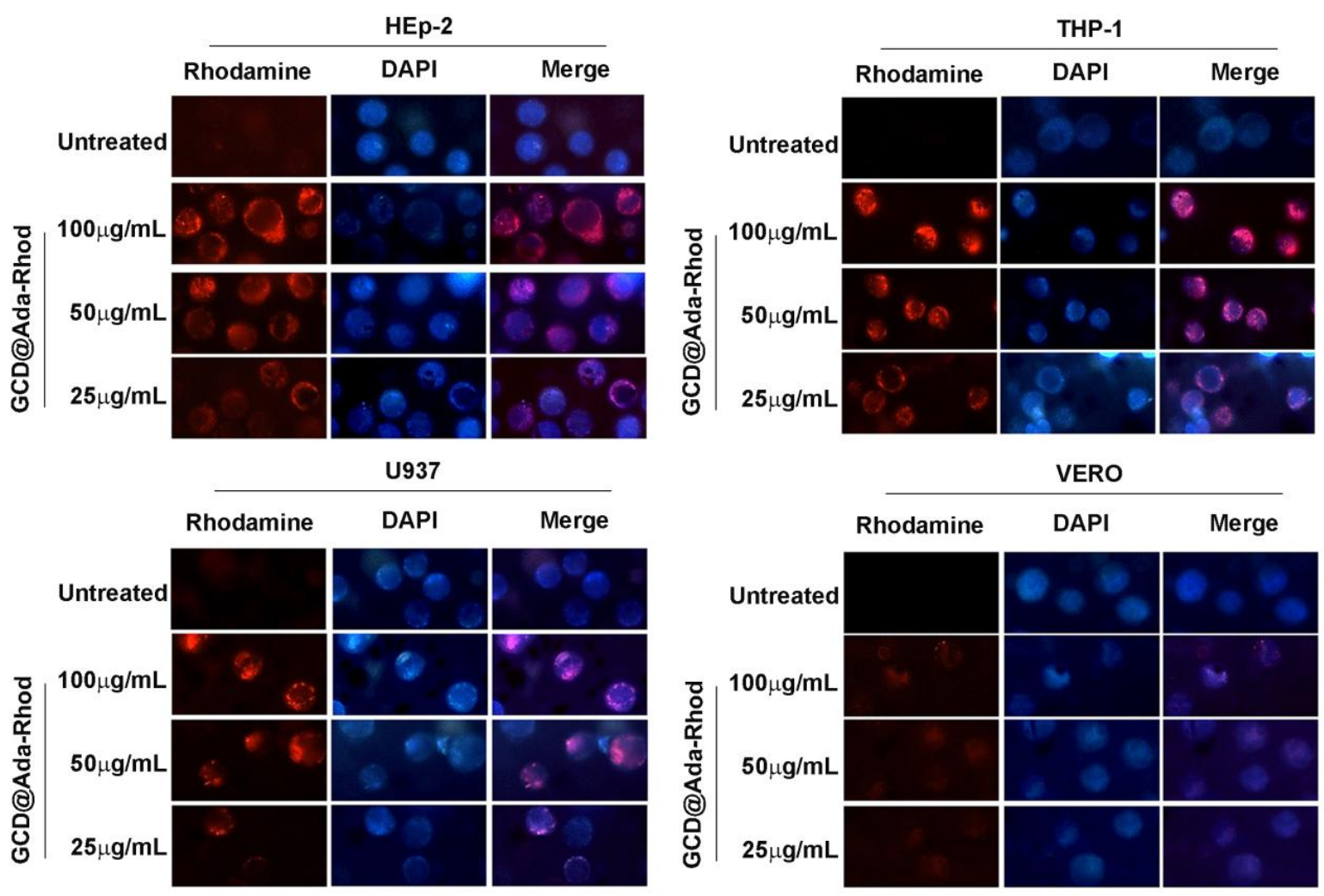

Figure S3. Cellular uptake of G-CD@ Ada-Rhod on HEp-2, THP-1, U937 and Vero cells. The cells were treated with different concentrations of G-CD@Ada-Rhod $(100 \mu \mathrm{g} / \mathrm{mL}, 50 \mu \mathrm{g} / \mathrm{mL}$ and $25 \mu \mathrm{g} / \mathrm{mL})$. Twenty-four hours later, the intracellular uptake of G-CD@ Ada-Rhod was analysed by using fluorescence microscopy. In all panels the Rhodamine filter captures the GCD@Ada-Rhod autofluorescence. 


\section{Cell viability assay}

The cell viability of Vero and HEp-2 cells treated with GCD@ADA-Rhod was determined on the basis of ATP levels using ViaLightTM plus cell proliferation and cytotoxicity bioassay kit according to the manufacturer's instructions (Lonza Group Ltd., Basel, Switzerland). Cells were grown in wells of 96-well plates and treated with different concentrations of GCD@ADA-Rhod. After $24 \mathrm{~h}$ the cells were harvested and the emitted light intensity related to ATP degradation was quantified with the GloMax Multi Microplate Luminometer (Promega Corporation, 2800 Woods Hollow Road Madison, WI, USA). The luminescence value was converted to the cell proliferation index $(\%)$ according to the following equation: Cell viability $\%=[(\mathrm{A}-\mathrm{B}) /(\mathrm{C}-\mathrm{B})] \%$

Where A denotes the average of treated sample, $\mathrm{B}$ represents background luminescence and $\mathrm{C}$ represents the average of untreated samples.

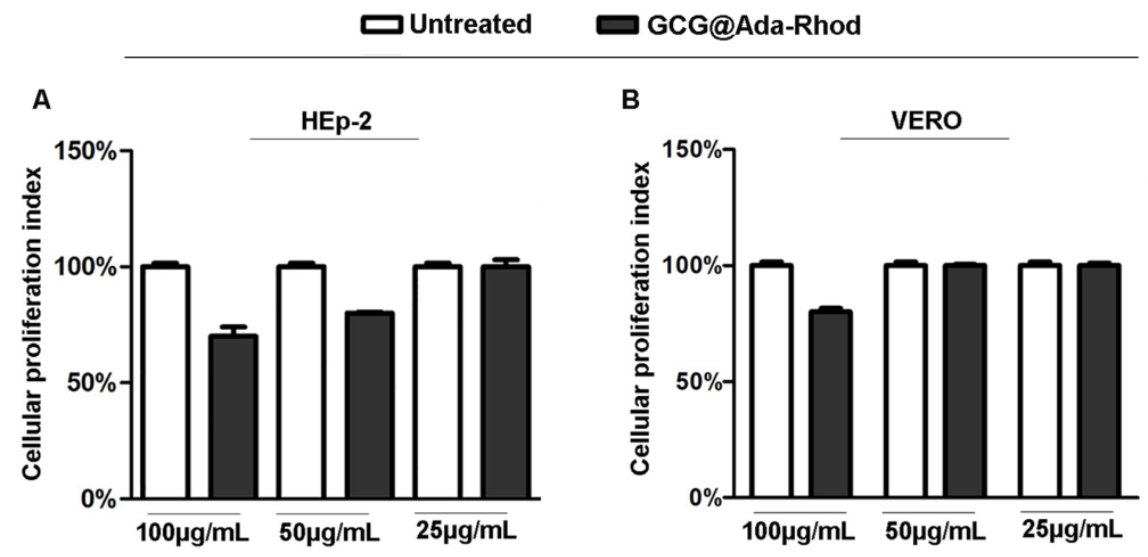

Figure S4. Viability assay in HEp-2 and Vero cells treated with GCD@ Ada-Rhod. The cell viability was determined on the basis of ATP levels using ViaLight ${ }^{\mathrm{TM}}$ plus cell proliferation and cytotoxicity bioassay kit (Lonza Group Ltd., Basel, Switzerland) in combination with GloMax ${ }^{\circledR}$ Multi Microplate Luminometer. HEp-2 and Vero cells were treated with three different concentrations of GCD@Ada-Rhod $(100 \mu \mathrm{g} / \mathrm{mL}, 50 \mu \mathrm{g} / \mathrm{mL}$ and $25 \mu \mathrm{g} / \mathrm{mL})$. Twenty-four hours of treatment, the samples were collected and the luminescence value was converted in cellular proliferation index $(\%)$ as described in Experimental. The assay was performed as means of triplicate \pm SD.

\section{REFERENCES}

1. B. J. Berne, R. Pecora, Dynamic Light Scattering, Wiley- Interscience, New York, 1976, pp. $1-376$. 